European journal of American studies

\title{
A Train to Hollywood: Porno-Chic in the Polish Cinema of the Late 1980s
}

Karol Jachymek

\section{(2) OpenEdition \\ Journals}

Electronic version

URL: https://journals.openedition.org/ejas/13625

DOI: $10.4000 /$ ejas. 13625

ISSN: 1991-9336

Publisher

European Association for American Studies

\section{Electronic reference}

Karol Jachymek, "A Train to Hollywood: Porno-Chic in the Polish Cinema of the Late 1980s", European journal of American studies [Online], 13-3 | 2018, Online since 07 January 2019, connection on 08 July 2021. URL: http://journals.openedition.org/ejas/13625 ; DOI: https://doi.org/10.4000/ejas.13625

This text was automatically generated on 8 July 2021 .

Creative Commons License 


\title{
A Train to Hollywood: Porno-Chic in the Polish Cinema of the Late 1980s
}

\author{
Karol Jachymek
}

1 This article is an attempt to analyze selected Polish films, produced in the second half of the 1980s, in the context of the erotic content included in these movies and references to broadly understood sexuality. Polish cinema of that period is full of erotic themes, which on one hand may be explained by the changing political and social situation as well as the transformation of social norms that was ongoing in the country at the time, and on the other by the influence of numerous American texts, or broadly defined western popular culture, that began permeating the country with an increasing boldness and led to clear eroticisation and even pornographication of Polish cinema at the time. In consequence, the so-called second wave of porno-chic (the term will be defined further in the article) that was taking place in the West, also impacted Polish cinema. Moreover, porno-chic became one of the catalysts of a revolution of the imagination (Krajewski) that was beginning to develop in Poland at the time. Therefore, this article analyzes selected films produced in the second half of the 1980s, which exemplify the above-noted process. The article also includes source materials, such as film reviews, commentaries of experts and archival texts that illustrate the significance of erotic themes in the Polish cinema of this period.

2 At the same time, it should be noted that the terms appearing in this article, such as "eroticisation," "pornographication," "sexual themes" (etc.), are sometimes used as synonyms, although clear differences in their meanings can easily be pointed out ("sexual themes" would mean the main or side plots of films centred around sexual issues, "eroticisation" would mainly refer to nudity or scantily dressed actors, etc., and "pornographication"-to bold scenes of sexual encounters). This decision mainly stems from the imprecise, and sometimes even an intuitive way in which such terms were used by commentators or experts at the time.

3 The turn of the 1980s and 1990s was undeniably the time when western popular culture succumbed to a visible pornographication. What it means is that nudity, as well as human sexuality (the latter usually perceived rather simplistically), started appearing 
in contemporaneous media and pop culture more boldly than before. There are at least a few, more or less direct, reasons for this interest in the issue of sexuality, including: the growth of academic discourse on pornography (which in fact initiated a broader discussion on this subject and in turn paved the way for issues of sexuality to cross into the public debate on a mass scale); the development of consecutive waves of feminism; the growing sexual awareness in the society (for instance, in the context of HIV/AIDS epidemic); the rise of LGBTQ+ culture and the voices of people who grew up during the sexual revolution (i.e. between 1960s and 1970s); as well as the commercial interest in sex as a marketing tool, according to the "sex sells" strategy (see McNair 63-64). Consequently, this sexualisation of pop culture, characteristic of the period under analysis, appeared under the name of "porno-chic." Nevertheless, Brian McNair observed that

Porno-chic is not porn... but the representation of porn in non-pornographic art and culture; the pastiche and parody of, the homage to and investigation of porn; the postmodern transformation of porn into mainstream cultural artefact for a variety of purposes including... advertising, art, comedy and education. (61)

It does not mean that porno-chic was only a part of a broadly understood entertainment or lacked deeper meaning. McNair adds:

Porno-chic aims to transfer the taboo, transgressive qualities of pornography to mainstream popular production, but in the knowledge that if media audiences are in general less easily shocked than in the past, mainstream culture remains a zone where real pornography is not acceptable. (70)

Porno-chic itself is not a brand-new phenomenon. Its first wave, also called "The Golden Age of Porn," can be traced back to the USA of the beginning of the 1970s. This is when pornography was destigmatized on a wider scale, and its transgressive potential was recognized for the first time. Therefore, various pornographic content was introduced into the mainstream, for instance: Mona. The Virgin Nymph (1970, directed by Michael Benveniste, Howard Ziehm), Boys in the Sand (1971, directed by Wakefield Poole), Devil in Miss Jones (1973, directed by Gerard Damiano), or, most importantly, Deep Throat (1972, directed by Gerard Damiano). At the time, those films enjoyed a wide viewership and were very successful commercially. The interest in explicit pornography, which reflected the ongoing sexual revolution, was mainly perceived as an expression of a counterculture stance. To put it briefly: conscious use of pornography was a protest against conservative and traditional values (see Williams, Power 99-119; Williams, Screening 130-154).

Although porno-chic of the first half of the 1970s was directly related to actual pornographic texts, the second wave (dating back roughly to the turn of the 1980s and 1990s) was focused on a different approach. Brian McNair explains:

Unlike the first wave of porno-chic in the 1970s, the resulting texts were not porn as such, but meta-pornographies works of all kinds, in every medium and genre, avant-garde and mainstream, fictional, scientific and journalistic, which talked about, referred to, or assumed on the part of their audiences a quite sophisticated familiarity with and understanding of pornography, not to mention a popular fascination for the subject which could legitimately be satisfied within the parameters of mainstream cultural production. (63)

7 To this extent, the issue of sexuality and pornography appeared, obviously, in the American cinema. In that period, the film industry created films such as American Gigolo (1980, directed by Paul Schrader), Cruising (1980, directed by William Friedkin), Risky Business (1983, directed by Paul Brickman), Nine 1/2 Weeks (1986, directed by Adrian Lyne), 
Blue Velvet (1986, directed by David Lynch), Pretty Woman (1990, directed by Gary Marshall), Basic Instinct (1992, directed by Paul Verhoeven), Indecent Proposal (1993, directed by Adrian Lyne), Colour of Night (1994, directed by Richard Rush), Showgirls (1995, directed by Paul Verhoeven), Striptease (1996, directed by Andrew Bergman), The People vs. Larry Flynt (1996, directed by Miloš Forman) or Boogie Nights (1997, directed by Paul Thomas Anderson). Despite a vast range of forms and genres as well as a variety of motifs included in the films, there is no doubt that each of these movies refers to the themes of sexuality and pornography in its own way, in some cases even artfully usurping them. Indeed, some provocative scenes from these films have not only become a part of the modern American cinematic canon, but they also serve as a proof of the impact of the second wave of porno-chic and of the social changes occurring at that time. Moreover, at the turn of the 1980s and 1990s, a new type of protagonist, an embodied perfection, had gradually become popular in American cinema and television, for example Arnold Schwarzenegger in Conan the Barbarian (1982, directed by John Milius) or Pamela Anderson in Baywatch (1989-2001) (see Holmlund).

8 It is worth noting that most of the above-mentioned tendencies, characteristic of American popular culture at the time, have also found their reflection in Polish cinema. The most prominent example is A Train to Hollywood (PociAg do Hollywood), directed by Radosław Piwowarski in 1987, the time when the influences of American cinema became highly noticeable in Polish productions. Not only does the title refer (intentionally or not) to Train Ride to Hollywood (1975), a mixture of comedy, musical, and fantasy directed by Charles R. Rondeau with Dan Gordon's screenplay, but the film also alludes to the work of Billy Wilder and Marilyn Monroe. The film's main protagonist is Mariola Wafelek (played by Katarzyna Figura) who lives in rural Poland, at the time when the communist regime is nearing its end. She works in a dining car on a train and everyone calls her Merlin (Marilyn), because she bears a striking resemblance to the famous actress. Mariola Wafelek has just one dream: she fantasizes about becoming a famous actress in Hollywood. In order to achieve this goal, she writes letters to her favourite director, Billy Wilder. Surprisingly, after a while, the beloved director responds to one of her letters.

9 Nonetheless, not only does the subject matter undertaken by Radosław Piwowarski indicate that the Polish cinema of that time was inspired by American (popular) films and Western pop culture, but the film can also be regarded as a Polish emanation of the second wave of porno-chic, mainly due to the presence of Katarzyna Figura, about whom Michael Goddard wrote: "Films with Katarzyna Figura usually balance between two genres: melodrama and soft porn (actually, the actress played in an episode of the erotic TV series Red Shoe Diaries and she posed for photos for Playboy)" (Goddard 279-280). A Train to Hollywood confirms Goddard's claims as an important aspect of the film seems to be the eroticized body of Katarzyna Figura, who undoubtedly shares a remarkable resemblance to Marilyn Monroe. Interestingly enough, the word "pociąg" in Polish has double meaning, i.e. both "a train" and "a sexual attraction." Thus, even though the film lacks any explicit allusions related to pornography, ${ }^{1}$ it could have been perceived as such. Especially since the movie ends with one of the most famous erotic scenes in the Polish cinema-a scene of a joyful splash in the nude, in a lake.

Evidently, A Train to Hollywood is not the only instance of a direct use of the porno-chic aesthetic in the Polish cinema. The turn of the 1980s and 1990s was the time of noticeable pornographication of both the Polish cinema and pop culture of the time. ${ }^{2}$ In 
the case of cinema, this process had started even earlier-at the beginning of the 1980s -and became even more noticeable in the second half of the decade. This is when numerous television and film productions appeared, including 07 zgłoś siz̨ (07 Come In, 1976-1987) by Krzysztof Szmagier, Andrzej Jerzy Piotrowski and Kazimierz Tarnas, Konopielka (1981) by Witold Leszczyński, Kamienne tablice (Stone Tablets) (1983) by Ewa Petelska and Czesław Petelski, Widziadło (The Phantom) (1983) by Marek Nowicki, Seksmisja (Sexmission, 1983) by Juliusz Machulski, Thais (1983) by Ryszard Ber, Bez końca (No End, 1985) by Krzysztof Kieślowski, Och, Karol (1985) by Roman Załuski, Medium (1985) by Jacek Koprowicz, Magnat (The Magnate, 1985) by Filip Bajon, Tulipan (The Tulip) (1986) by Janusz Dymek and Andrzej Swat, tuk Erosa (Eros's Arch) (1987) by Jerzy Domaradzki, Życie wewnĘtrze (The Inner Life) (1986) and Porno (Porn) (1989) by Marek Koterski, Sztuka kochania (The Art of Love) (1989) by Jacek Bromski, Co lubia tygrysy (What Tigers Like) (1989) by Krzysztof Nowak or In flagranti (1991) by Wojciech Biedroń. Although none of these films was strictly pornographic, the more or less gratuitous erotic scenes and/or explicitly sexual subject matter played a crucial role in the movies.

11 The reasons for this phenomenon might be found in several processes occurring simultaneously at that time. Firstly, the 1980s in Poland witnessed a general "loosening" of social norms in the socio-cultural environment of the time (which can be directly related to such factors as changes in the western culture and the second wave of porno-chic). ${ }^{3}$ Secondly, the popularisation and pornographication of films produced in that period carried political significance. After the martial law was declared in Poland on December 13, 1981, the 1980s saw "one of the biggest challenges ever to the legitimacy of the communist power" (Zaremba 383). Therefore, the government strove for a swift neutralization of the spreading anti-government sentiments. "The only system of values that, in broad opinion, could attract social activism was the ethos of the Solidarity movement. Therefore, the purpose was to neutralize it by engineering a quick 'atomization' of the community" (Kornacki 202). One way to accomplish that goal was to attract a great number of people to the cinema. The strategy of the government relied on the assumption that an easy access to entertainment and attractive films would divert people's attention from antigovernmental activity (see Kalinowska; Lubelski 547). Thirdly, despite the socialist system, "[t]he 1980s [were] a period of a visible commercialisation of the Polish cinema. Box office success achieved by individual film productions and by the film industry at large was always-contrary to a common belief-an important indicator of the films' value, but in the 1980s making a profit by film studios and the entire film industry became a priority" (Kornacki 201, see also: Adamczak).

One of the most interesting examples of how, with the help of nudity, (an excess of) erotic scenes and (para)sexual themes, filmmakers attempted to attract big numbers of moviegoers is the aforementioned comedy co lubia tygrysy (What Tigers Like) by Krzysztof Nowak. The film premiered on April 24, 1989, but the preproduction started in 1986. It was a story about two middle-aged men, Marek (played by Krzysztof Kowalewski) and Piotr (played by Wojciech Pokora), who go on holidays to Sopot (a Polish seaside resort). Marek, who is married, wants to cheer up his friend Piotr, whose wife has just left him. As a result, they succumb to a whirlwind of tantalizing holiday temptations, which are related to various aspects of sexuality. Therefore, the film was full of numerous love affairs, beautiful women sunbathing on the beach, 
nymphomaniacs, passionate lovers, seaport prostitutes (called "seagulls" by the protagonists), dancing parties and strip bars. Moreover, the film Co lubia tygrysy also satirized several sex-related issues, such as: the HIV/AIDS epidemic (which was happening around the world at the time), homosexuality and sex counselling (conducted by the means of mass media, such as TV programs or columns in newspapers). One might even risk a statement that, viewed from this angle, the film was an excellent reflection of the transformation of social norms taking place in Poland and in the West at the time.

Even though the film Co lubia tygrysy is not an example of refined humour, it was fairly well received by the members of Komisja Kolaudacyjna Filmów Fabularnych (the Feature Film Pre-Screening Commission, being a body of experts responsible for the assessment and rating of feature films, including aspects liable for political censorship) at its meeting on December 20,1988. Noticeably, the positive reaction towards the film was not at all based on the artistic value of the piece. The Commission members believed that cinemagoers would be lured into theatres by the nudity and erotic scenes. One of them, Stanisław Trepczyński, opined: "It is a skilfully-made comedy; there are pretty girls, a lot of amusing scenes-it is pleasing to watch" ("Stenogram"). Another, Czesław Dondziłło, added: "I ought to side with the majority of positive reviews, despite the fact that I personally do not have a liking for comedy; but I know that this kind of films meets with approval when it comes to both pre-war as well as contemporary comedies" ("Stenogram"). While Tadeusz Chmielewski explained: "It should be admitted that the comedy is quite simplistic, there is no complexity of any kind, but what is crucial is that the jokes do not cross the boundaries of good taste; we intended to make a popular comedy, and we assumed that the viewers would just have fun watching it" ("Stenogram"). Jerzy Schönborn, the chairman of the proceedings, used this occasion to comment on what in his opinion was an unrefined sense of humour on the part of general audience:

Surely this type of humour is not especially subtle, but if we want to attract a wide range of audiences, then we cannot expect subtle jokes, because they could become obstacles in watching the film, but I do agree that in this case we are not talking about this film being art, but rather a popular film, of the kind that is in demand, and I am convinced that many people will watch it.... I believe that the director will get his royalties and the cinemagoers their dose of fun. ("Stenogram")

Although after the premiere Co lubia tygrysy did not meet with many positive opinions and reviews, ${ }^{4}$ the goal was achieved. In the end, the comedy enjoyed a relatively big commercial success and attracted a lot of viewers. Undoubtedly, there could be many reasons for this wide interest in the movie, but one of them was evidently the most important. Erotic scenes and the (para)sexual subject matter were indeed what the Polish audience had already known for a while and what people wanted to watch. ${ }^{5}$ More significantly, the sexual references and the porno-chic aesthetic in these films was a proof of their "westernization" and this particular characteristic carried exceptionally strong connotations. As Marek Krajewski noted, the late 1980 s was the period when non-western content

was replaced by videocassettes with movies such as Conan, Rambo, Lemon Popsicle (also known as Eskimo Limon) [an Israeli TV series], and Bavarian pornographic films, while television screens were occupied by Sabrina, CC Catch, Modern Talking, stars of italo disco, break-dance, and aerobic, but most importantly by representations of the ordinary lives of people living in the western world, people with problems so different from those experienced by Poles. ("Koniec lat 80-tych") 
This saturation of the Polish socio-cultural reality of the late 1980s with an excess of "pictures from the other side," as Krajewski called them, in consequence led to dramatic changes in the Polish media:

The films shown in cinemas (Tabu, Łuk Erosa, Widziadło, Medium) contained bold erotic scenes, while public television attempted to compete against VHS players and satellite TV with the first Polish soap opera (W labiryncie, In the Labyrinth), late night screenings of soft-porn (Różowa seria) (The Pink Series), and entertainment programs showing music videos (Jarmark, The Fair). These new media experiences not only altered the Polish tastes that defined good entertainment, music, and film, but they also affected the people's imagination by creating new standards of normalcy related to clothing, hairstyles, vehicles, home décor and interpersonal relations. These standards, as never before, made the gap between the reality that was and the reality that could be, clearly visible, objective and perceivable. ("Koniec lat 80tych")

17 The second half of the 1980s in Poland was a time of the so-called revolution of imagination-a process which in the long run led to a remodelling of awareness of ordinary Poles. This remodelling was mostly possible thanks to the new forms of audiovisual messages appearing with increasing boldness during the last years of the communist regime, and to the realities of the political transformation itself, because "what in the 1980s enabled a connection with the global production systems and the systems of standardization of dreams, were the innovative communication technologies, mainly VHS players and satellite dishes" (Krajewski). These technologies helped to supply the imagination of Poles with different types of media representations than before, and in turn these representations, so different from their socialist reality, became one of the factors that propelled the upcoming change. ${ }^{6}$ A change so significant that, in essence, it was not just a simple adjustment of common assumptions related to the way the world or daily life should look like. The proof of the striking power of this change was primarily manifested by the fact that it "introduced to the awareness of Poles entirely new parameters, which delocalized their existence" (Krajewski). In that period, "simple dichotomies such as East-West, Eastern Bloc-Western Bloc, USSRUSA, communism-capitalism" (Krajewski) were no longer enough to define one's identity. It all happened mainly due to the pictures and the mass media circulating in our consciousness, which, on a large scale, broadened the perception of the reality that we had known so far. One of the key catalysts of this process were undoubtedly videocassette players and videocassettes with western-made films that heavily influenced the cultural norms in Poland at that time. As noted by Mirosław Filiciak and Patryk Wasiak, "[r]eading Proust was replaced by watching films with Sylvester Stallone or Arnold Schwarzenegger, while the western origin of the technology itself, alongside with the content, made the attack on the old hierarchies very successful" (90).

The content which at the time influenced the change in the hierarchy of values also included erotic scenes and sexual themes, known to the wide audience not only from pornographic films (noticeably enjoying a huge popularity in Poland at the time), ${ }^{7}$ but also from increasingly available, diverse texts of western popular culture that employed a porno-chic aesthetic. The popularity of these elements helped them to successfully enter the Polish cinematography. Nevertheless, they were not expected to play a transgressive function (as in classic porno-chic texts), but to serve the objectives of the government, by neutralising anti-governmental sentiments and generating a 
commercial profit. However, their impact proved to be much more revolutionary than intended by the authorities. As noted by Izabela Kalinowska:

[I]t might be perversely admitted that the cultural politics of the last decade of the Communist regime, especially the permissiveness towards sex, brought an effect that was contradictory to what was expected: the commercialised physicality appearing on television and on the screens of movie theatres during the 1980s, had prepared the setting for the upcoming change that transformed the urban and rural working masses into consumers of pop culture. (78)

In this manner, the onscreen nudity and erotic scenes appearing with increasing frequency in Polish (and foreign) films at the turn of 1980s and 1990s, to a certain extent contributed to the transformation of the socio-cultural reality. Nevertheless, it is worth emphasizing that the new types of representation which then became common in the media were deeply misogynistic, evidently intertwined with the patriarchal system and openly objectifying women. The eroticisation and pornographication of popular culture analysed in this article, in particular concerned women whose bodies were presented as attractive objects to look at. One should note here that this tendency is characteristic for nearly all of Polish cinematographic discourse, and the cinema in general, women being still commonly represented from the male point of view. However, this larger issue lies beyond the scope of this article.

Nevertheless, there is no doubt that the reality of the second half of the 1980s was profoundly dominated by the conventions characteristic of the American, or broadly understood western, popular culture. The above-noted films were clear examples of this phenomenon, as the film makers of the time eagerly borrowed from the conventions used in the western cinema. One of those conventions, as it was shown in this article, was the porno-chic aesthetic, which was employed with increasing boldness in a great number of films produced at the time. In consequence, all the changes analysed in this article became catalysts for the so-called revolution of imagination (Krajewski) which was beginning in Poland in the second half of the 1980s -a process which paralleled the transformation of the political system, ongoing in Poland at the time.

\section{BIBLIOGRAPHY}

Adamczak, Marcin. Globalne Hollywood, filmowa Europa i polskie kino po 1989 roku. Przeobrażenia kultury audiowizualnej przełomu dziesiĘcioleci. Gdańsk: słowo/obraz terytoria, 2010. Print.

Filiciak, Mirosław, and Patryk Wasiak. “Wypożyczalnia rewolucji.” Polityka 22 (2013): 88-91. Print.

Goddard, Michael. “'Figura' postkomunistycznego pożĄdania? Role Katarzyny Figury albo: jak polskie kino stało siĘ popularne.” Kino polskie: reinterpretacje. Historia-ideologia-polityka. Ed. Konrad Klejsa and Ewelina Nurczyńska-Fidelska. Kraków: Wydawnictwo RABID, 2008. 275-286. Print. 
Holmlund, Chris. Impossible Bodies, Femininity and Masculinity at the Movies. London: Routledge, 2002. Print.

Jachymek, Karol. “Seks w kinie polskim okresu PRL.” Pleograf. Kwartalnik Akademii Polskiego Filmu 1 (2018). Web.

http://www.akademiapolskiegofilmu.pl/pl/historia-polskiego-filmu/artykuly/seks-w-kiniepolskim-okresu-prl-wprowadzenie/626. Accessed 7 Aug. 2018.

Kalinowska, Izabela. "Seks, polityka i koniec PRL-u: o cielesności w polskim kinie lat osiemdziesiątych.” Ciało i seksualność w kinie polskim. Ed. Sebastian Jagielski and Agnieszka Morstin-Popławska. Kraków: Wydawnictwo Uniwersytetu Jagiellońskiego, 2009. 63-78. Print.

Kornacki, Krzysztof. “Naga władza. Polskie kino erotyczne (schyłkowego PRL-u).” Studia Filmoznawcze 29 (2008): 195-225. Print.

Kornatowska, Maria. Eros i film. Łódź: Krajowa Agencja Wydawnicza, 1986. Print.

Kowalczyk, Andrzej Z. “Co lubiĄ widzowie?.” Sztandar Ludu 122 (1989): 9. Print.

Krajewski, Michał. “Koniec lat 80-tych. Rewolucja wyobraźni.” I love Poland, by Mariusz Forecki. ZwiĄzek Polskich Artystów Fotografików. Poznań: OkrĘg Wielkopolski, 2009. Web.

https://www.academia.edu/2540689/Koniec_lat_80-tych._Rewolucja_wyobraźni Accessed: 5 Aug. 2018.

Lubelski, Tadeusz. Historia kina polskiego 1895-2014. Kraków: Wydawnictwo Uniwersytetu Jagiellońskiego, 2015. Print.

McNair, Brian. Striptease Culture: Sex, Media and the Democratization of Desire. London an New York: Routledge, 2002. Print.

“Stenogram z posiedzenia Komisji Kolaudacyjnej Filmów Fabularnych w dniu 20 grudnia 1988 r. Na porzĄdku dziennym: omówienie filmu pt. Co lubią tygrysy - zrealizowanego przez reż. Krzysztofa Nowaka w Zespole 'Oko'.” Archiwum Filmoteki Narodowej, signature: A-344, position: 574. Print.

Williams, Linda. Hard Core: Power, Pleasure, and the "Frenzy of the Visible". Los Angeles: University of California Press, 1989. Print.

---. Screening Sex. Durham and London: Duke University Press, 2008. Print.

Zaremba, Marcin. Komunizm, legitymizacja, nacjonalizm. Nacjonalistyczna legitymizacja władzy komunistycznej w Polsce. Warszawa: Wydawnictwo TRIO, 2001. Print.

Zatorski, Janusz. “Tygrysy i pasikoniki.” Kierunki 27 (1989): 15. Print.

\section{NOTES}

1. It is worth noting that during the communist regime, pornography was not easily available in Poland, due to censorship. Hence, erotic scenes included in Polish film productions enjoyed a different status and had a considerable impact. It does not mean that the Polish audience had no access to any pornographic content, as pornographic publications and films, particularly in the 1980s, were often smuggled in from the West. 2. In addition, in 1986 Maria Kornatowska published her famous book Eros i film (Eros and Film), which certainly confirmed the presence of eroticism in popular culture. 
3. As I have written in Pleograf: "In 1983, books such as Seks partnerski (Partners in Sex) by Zbigniew Lew-Starowicz, a renowned Polish psychiatrist and psychotherapist specialising in sexology, or the scandalous novel Raz $w$ roku $w$ Skiroławkach (Once a Year in Skiroławki) by Zbigniew Nienacki, were published. Moreover, after a 20-year hiatus, the Polish Beauty pageant, Miss Polonia, returned. The new television executives agreed to broadcast the 'pink' series of erotic films, while in the second half of the decade, TVP (Polish public TV, the only television broadcaster at the time) ran a Polish erotic program charmingly named Sekscesy (a play on words 'sex' and 'excess'). Marketing merchandise, such as calendars, pens, cards, etc., depicting naked women, was very popular at the time, and was distributed by almost all 'respectable' businesses. Nudism was also gaining in popularity; it was supported by Veto. Tygodnik Każdego Konsumenta (Veto. The Weekly of Every Consumer), and its presence in pop culture owed much to a song Chałupy welcome to, sung by Zbigniew Wodecki (Chałupy is a popular seaside resort in Poland, famous for its nude beach). Under the auspices of the Polish Naturist Association, lonely hearts' clubs began to pop up here and there, articles about the emerging swingers lifestyle could be found and some magazines, such as Relaks $i$ Kolekcjoner Polski (Relax and Polish Collector) published private sex offers. Gay communities became more visible and began to establish their own structures and organisations, although from 1985 to 1987 they were under the scrutiny of Milicja Obywatelska (the communist regime police force) in an operation dubbed 'Hiacynt.' By the end of the 1980s, in news kiosks one could buy, published in Poland, magazines 'for men' that did not shy away from erotic content, such as the monthly Pan. Magazyn Poradniczo-Hobbystyczny (Mister: Advice and Hobby Magazine). In December 1992, three years after the fall of the communist regime, the first issue of the Polish Playboy was published, with Malwina Rzeczkowska as the playmate (posing in the style and setting straight out of Dynasty). At the time, first Polish pornographic publications also appeared on the market, including Wamp. Pikantny Magazyn dla Koneserów (Vamp: Hot Magazine for Connoisseurs), Nowy Wamp (New Vamp), Men, and Nowy Men (New Men) to name a few" (Jachymek).

4. Accordingly, Andrzej Z. Kowalczyk wrote for Sztandar Ludu (The Banner of the People): "What do cinemagoers like? It is simple: nudity, dirty thoughts, cussing, and burlesque. In case you do not believe me, here are a few examples: the scene in which a stripper takes off her clothes-the audience reacts with murmurs of approval and muffled giggles; Anna Chodakowska ridicules Wojciech Pokora, calling him an impotent-the audience bursts out laughing; while Bożena Dykiel tries (and fails) to take off the dress over her head, she exposes her breasts, and finally falls over-the audience roars with laughter and applauds (sic!); identical reaction occurs during the scene with the word 'faggot' in it. This is what cinemagoers like. This is what tigers like..." (Kowalczyk 9).

5. In one of the reviews of the film Co lubią tygrysy an outraged critic wrote, "The audience is wooed by the naked bodies in the posters and treated as a dreary, drooling over a naked thigh erotomaniac, which is a cardinal mistake or even an act of stupidity. Erotomaniacs, or people-mildly speaking-particularly interested in sex on the screen, have hundreds of videocassettes at their disposal, and they are not interested in the nudity of a few amateur actresses; these people watch Caligula, Emmanuelle or hardporn. I demand that the filmmakers put a stop to treating these cinemagoers as if they were complete morons and start making films about love and eroticism for normal 
people at once!" (Zatorski 15). However, it should be mentioned that Zatorski was wrong because the Polish audience eagerly watched these types of films.

6. However, this media revolution was a phenomenon occurring simultaneously in the West. As pointed out by Marek Krajewski, "It should be kept in mind that while changes were taking place in our country, the well-developed capitalist countries were experiencing a rapid media revolution, whose products, such as CNN, MTV, satellite television, VHS players, CD players, and Walkmen, allowed information and most of all pictures, to flow freer than ever before, in a way that was not limited by political and ideological boundaries."

7. In the opinion of Filiciak and Wasiak, "The working class was yearning for sex. In 1986, Tygodnik Polski claimed that 60 percent of videocassettes detained on the border were 'against the Polish moral code."”

\section{ABSTRACTS}

Polish cinema in the late 1980s-a period marked in Poland by a transformation of social norms and a mounting pressure on the political authorities from the illegal opposition movementunderwent a significant evolution, part of which was opening up to erotic content reaching Poland from the West in various forms, including the "porno-chic" phenomenon, defined by Brian McNair as being "not porn... but the representation of porn in non-pornographic art and culture." In my article, I look at some major examples of the porno-chic trend in Polish cinema of the late 1980s and draw on the archival records from the Film Pre-Screening Commission to demonstrate how the political and cultural authorities of the time attempted to co-opt the new "western" trend to improve their standing with an increasingly irate public and to deflate the rising discontent by a supply of an attractive cultural and erotic content.

\section{INDEX}

Keywords: porno-chic, Polish cinema, film censorship, Poland-Western influences, eroticism

\section{AUTHOR}

\section{KAROL JACHYMEK}

Karol Jachymek, Ph.D., works as an assistant professor at the SWPS University of Social Sciences and Humanities in Warsaw. He specializes in the social and cultural history of cinema (particularly Polish), the methodology of history, the problematics of the body, sex and sexuality, and media influence on individual and collective memory. His interests also include the sociocultural contexts of social networks, blogs and vlogosphere. He is the author of the book Film ciało - historia. Kino polskie lat sześćdziesiątych [Film-Body-History: Polish Cinema of the Sixties]. 